\title{
Development and Clinical Application of
}

\section{a New Method for the Radioimmunoassay of Arginine Vasopressin in Human Plasma}

\author{
Gary L. Robertson, Ermelinda A. Mahr, Shahid Athar, and \\ TUSHAR SinHa \\ From the Department of Medicine, Indiana University Medical Center and the \\ Veterans Administration Hospital, Indianapolis, Indiana 46202 and \\ Abraham Lincoln School of Medicine and Veterans Administration, \\ West Side Hospital, Chicago, Illinois 60680
}

A в S T R A C T A radioimmunoassay has been developed that permits reliable measurements of plasma arginine vasopressin (AVP) at concentrations as low as 0.5 $\mathrm{pg} / \mathrm{ml}$ in sample volumes of $1 \mathrm{ml}$ or less. Nonhormonal immunoreactivity associated with the plasma proteins is eliminated by acetone precipitation before assay, leaving unaltered a component that is immunologically and chromatographically indistinguishable from standard AVP. Storage of plasma results in a decline in AVP concentration and, thus, must be carefully regulated. The plasma AVP values obtained by our method approximate the anticipated levels and vary in accordance with physiologic expections. In recumbent normal subjects, plasma AVP ranged from (mean \pm SD) $5.4 \pm 3.4$ $\mathrm{pg} / \mathrm{ml}$ after fluid deprivation to $1.4 \pm 0.8 \mathrm{pg} / \mathrm{ml}$ after water loading, and correlated significantly with both plasma osmolality $(r=0.52: P<0.001)$ and urine osmolality $(r=0.77 ; P<0.001)$. After fluid restriction, plasma AVP was uniformly normal relative to plasma osmolality in patients with nephrogenic diabetes insipidus and primary polydipsia but was distinctly subnormal in all patients with pituitary diabetes insipidus. The infusion of physiologic amounts of posterior pituitary extract caused a dose-related rise in plasma vasopressin that afterwards declined at the expected rate $\left(\mathrm{t}_{\frac{1}{2}}=22.5 \pm\right.$ $4 \mathrm{~min}$ ). We conclude that, when used appropriately, our radioimmunoassay method provides a useful way of assessing AVP function in man.

Preliminary aspects of this work were published in abstract form in 1971. Clin. Res. 19: 562.

Received for publication 5 February 1973 and in revised form 13 April 1973.

\section{INTRODUCTION}

Efforts to study the physiology of the antidiuretic hormone, arginine vasopressin (AVP), ${ }^{1}$ have long been hampered by the lack of a simple and sensitive method for measuring the hormone in blood and other biologic fluids. We previously described a procedure for the radioimmunoassay of vasopressin that was capable of measuring the hormone at physiologic concentrations in relatively small volumes of plasma (1). Due to certain characteristics of that antiserum, however, it was necessary to isolate chromatographically and concentrate plasma vasopressin before assay, a requirement that significantly limited the speed and efficiency of the technique.

The acquisition of a sensitive new antiserum (2) has now made possible the development of a much simpler method for radioimmunoassay of vasopressin in biologic fluids. When used with a simple acetone-extraction technique, this assay permits precise measurements of plasma vasopressin at concentrations as low as 0.5 $\mathrm{pg} / \mathrm{ml}(0.2 \mu \mathrm{U} / \mathrm{ml})$ in plasma volumes of less than 1 $\mathrm{ml}$. The values obtained are quantitatively similar to those found with our previous more elaborate method (1) and conform well to physiologic expectations in both normal and disordered states of water metabolism. The characteristics of this new assay and its application

\footnotetext{
${ }^{1}$ Abbreviations used in this paper: AVP, arginine vasopressin; $\mathrm{AVP}_{\mathrm{B}}$, natural $\mathrm{AVP} ; \mathrm{AVP}_{\mathrm{G}}$, second preparation of natural AVP; AVPs, synthetic AVP; AVT, synthetic arginine vasotocin; $B / F$, bound-to-free; Gl-1, antiserum Glick-1; LVP, synthetic lysine vasopressin; OXY, synthetic oxytocin; $\mathrm{P}_{\mathrm{AVP}}$, plasma AVP.
} 
to physiologic studies of plasma vasopressin will be described in this paper.

\section{METHODS}

Reagents. Antiserum Glick-1 (Gl-1) used in these studies was provided by Dr. Seymour Glick (2). It was diluted $1: 10$ with $0.02 \mathrm{M}$ phosphate buffer $(\mathrm{pH}=7.4)$ and stored in glass at $-20^{\circ} \mathrm{C}$. Working solutions are prepared at 4-mo intervals by diluting the storage stock 1,000-fold with buffer containing $0.02 \mathrm{M}$ phosphate $(\mathrm{pH}=7.4), 0.14$ $\mathrm{M} \mathrm{NaCl}$, and control rabbit serum $(10 \mu \mathrm{l} / \mathrm{ml})$.

Natural AVP $\left(\mathrm{AVP}_{\mathbf{B}}\right)$, purified from bovine pituitary (3), was a gift of Dr. Jesse Roth. It has an antidiuretic potency of approximately $400 \mathrm{U} / \mathrm{mg}$, showed no ninhydrinreacting contaminants on ascending paper chromatography in butanol:acetic acid: water, $4: 1: 5$, and gave equimolar amounts of the appropriate amino acids on amino acids analysis (1). When dissolved at a concentration of $1 \mathrm{mg} / \mathrm{ml}$ in $0.2 \mathrm{~N}$ acetic acid and stored in glass at $-20^{\circ} \mathrm{C}$, this preparation has shown no change in immunologic potency in over 36 mo. However, more dilute solutions of $\mathrm{AVP}_{\mathbf{B}}$, such as the working stock used to prepare the standard curves $(500 \mathrm{ng} / \mathrm{ml})$, undergo a significant decrease in immunologic potency when stored for more than $4 \mathrm{mo}$ and, therefore, must be prepared at frequent intervals from the concentrated stock.

A second preparation of natural AVP $\left(\mathrm{AVP}_{\mathrm{G}}\right)$ was provided by Dr. Jack George. It had been purified from bovine pituitary by a modification of the method of Acher, Light, and du Vigneaud (3), using gel filtration instead of ionexchange chromatography. The biologic potency of the $\mathrm{AVP}_{\mathbf{G}}$ has not been determined but, like the $\mathrm{AVP}_{\mathbf{B}}$, it contained no ninhydrin-reacting contaminants on paper chromatography.

Synthetic AVP (AVPs) was purchased from Schwarz/ Mann (Schwarz/Mann Div., Becton, Dickinson \& Co., Orangeburg, N. Y.) (lot X-2024). This preparation had a designated pressor potency of $300 \pm 20 \mathrm{U} / \mathrm{mg}$, revealed a single ninhyrin-reacting contaminant in several chromatographic systems and, on amino acid analysis, contained a $30 \%$ molar excess of unspecified amino acids.

Synthetic arginine vasotocin (AVT), was purchased from Schwarz/Mann (lot X-2129). It had a designated pressor potency of $117 \pm 16 \mathrm{U} / \mathrm{mg}$, revealed a trace amount of ninhydrin-reacting contaminant on thin-layer chromatography and, on amino acid analysis, appeared to contain a $16 \%$ molar excess of unspecified amino acids. Synthetic lysine vasopressin (LVP), purchased from Nutritional Biochemicals Corp. (Cleveland, Ohio) had a potency of about 100 $\mathrm{U} / \mathrm{mg}$. Synthetic oxytocin (OXY) purchased from Mann Research Labs, Inc., (New York) had a potency of 10 $\mathrm{U} / \mathrm{mg}$.

[225]]AVP was prepared from purified bovine hormone $\left(\mathrm{AVP}_{\mathbf{B}}\right)$ as previously described $(1,4)$. This procedure yields a radioiodinated product that is homogeneous on paper chromatography, is $90 \%$ bound by excess vasopressin antiserum, and has an immunologically determined specific activity of approximately $1,000 \mu \mathrm{Ci} / \mu \mathrm{g}$. As usually performed, one iodination provides enough [ $\left.{ }^{205} \mathrm{I}\right] \mathrm{AVP}$ for about 2,000 assays and when stored at $-20^{\circ} \mathrm{C}$ is stable for 4-6 wk.

[ ${ }^{125}$ I]AVP also was prepared from a purified synthetic hormone, AVPs. This preparation yields a radioiodinated product that is only $75-85 \%$ bound by excess vasopressin antiserum but gives useful standard curves and unknown

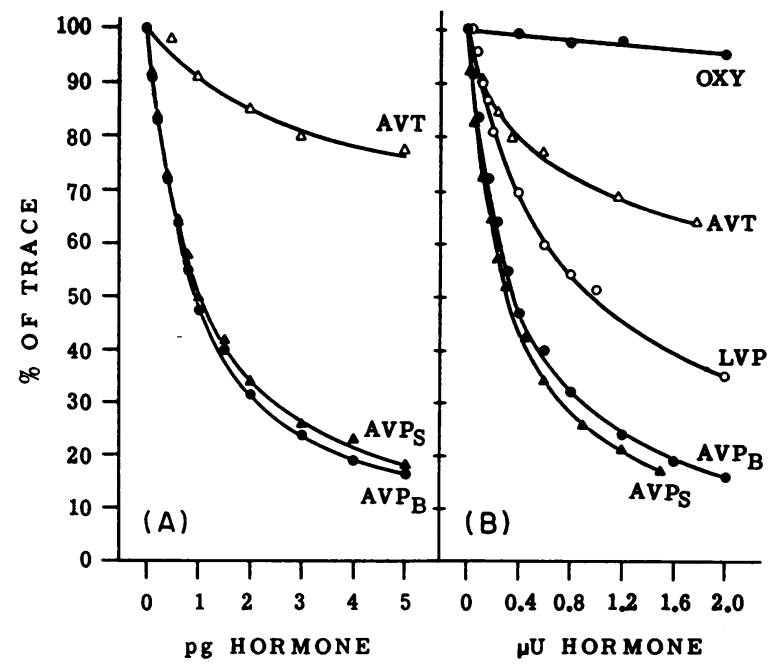

FIgLRE 1 Sensitivity and specificity of the G1-1 assay. Panel A depicts the immunologic reactivity, in relation to weight, of three purified preparations of nonapeptide hormone; (a) bovine AVP $\left(\mathrm{AVP}_{\mathbf{B}}\right)$; (b) synthetic AVP $\left(A V P_{s}\right)$; and (c) synthetic arginine vasotocin (AVT). Another purified preparation, $\mathrm{AVP}_{\mathrm{G}}$, gave a displacement curve identical with $\mathrm{AVP}_{\mathrm{B}}$ and is not shown here. Panel $\mathrm{B}$ depicts the immunologic reactivity, expressed in terms of biologic activity, of $\mathrm{AVP}_{\mathbf{B}}, \mathrm{AVP} \mathrm{P}_{\mathrm{s}}$, and $\mathrm{AVT}$, as well as partially purified preparations of synthetic lysine vasopressin (LVP) and oxytocin (OXY).

values comparable to those obtained with the tracer prepared from $\mathrm{AVP}_{\mathbf{B}}$.

The diluent used in the assay contains $0.033 \mathrm{M}$ veronal buffer ( $\mathrm{pH}=8.6$ ), $0.14 \mathrm{M} \mathrm{NaCl}, 0.017 \mathrm{M}$ disodium EDTA, $48 \mu \mathrm{g} / \mathrm{ml}$ L-cystine (Sigma Chemical Co., St. Louis, Mo.), and $4.2 \mathrm{mg} / \mathrm{ml}$ crystalline bovine serum albumin (Pentex). Only crystallized albumin is used since most of the less purified preparations have been found to interfere significantly in the assay.

The polyethylene glycol used to precipitate antibody (5) was prepared by dissolving $250 \mathrm{~g}$ of Carbowax 6000 (Union Carbide Corp., Chemicals \& Plastics, New York) in 1 liter distilled water.

Sample preparation. Clinical studies were conducted with the subjects recumbent for $30-45 \mathrm{~min}$ at an ambient temperature of $25^{\circ} \mathrm{C}$. Blood was obtained by venesection into lithium heparin vacutainers (Becton, Dickinson \& Co., Rutherford, N. J.), immediately chilled to $4^{\circ} \mathrm{C}$, and centrifuged for $20 \mathrm{~min}$. Osmolality was determined on the fresh plasma by freezing-point depression (Advanced Instruments Inc., Needham Heights, Mass., Osmometer model $3 \mathrm{~L})$. Unless otherwise indicated, the plasmas were then stored in glass vials (Kimax, Kimble Products Div., OwensIllinois, Inc., Toledo, Ohio) at $-20^{\circ} \mathrm{C}$ for $4-12$ wk before extraction and assay. The AVP values obtained at that time are not corrected for the losses that occur during the storage period (vide infra).

Acetone extracts were prepared by mixing $1 \mathrm{ml}$ of the thawed plasma with $2 \mathrm{ml}$ of cold acetone to precipitate plasma proteins. After centrifugation at $2,100 \mathrm{rpm}$ for 40 min, the clear yellow supernate was decanted from the precipitate, thoroughly mixed with $5 \mathrm{ml}$ of cold petroleum ether and centrifuged again, and the top phase was carefully 


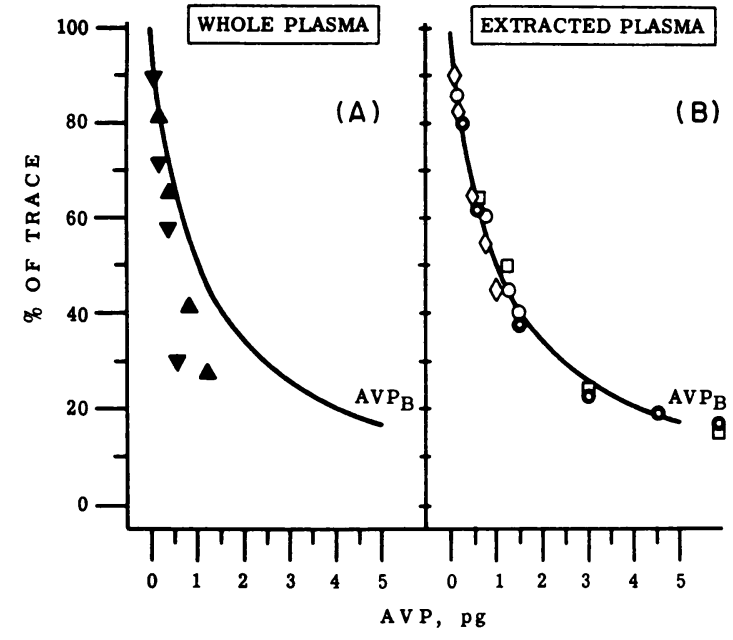

Figure 2 The immunologic cross-reactivity of plasma before and after acetone extraction. Panel A shows the displacement curve obtained when whole plasma from two normal subjects was assayed in volumes ranging from 0.05 to $0.3 \mathrm{ml}$. Panel B shows the results obtained when acetoneextracted plasmas from four normal subjects were assayed in volumes ranging from 0.01 to $0.2 \mathrm{ml}$. In both panels, the solid line represents the displacement curves obtained with $\mathrm{AVP}_{\mathbf{r}}$.

aspirated and discarded. This step eliminated most of the acetone, plasma lipids, and a small amount of plasma water. The acetone remaining in the lower aqueous phase was eliminated by gentle stirring at $4^{\circ} \mathrm{C}$ under a stream of room air for 15-20 min or until the residue gave an negative test for acetone (nitroprusside test). This consistently

\section{TABLE I}

The Immunologic Reactivity of A VP after In Vitro Incubation with Various Tissues

\begin{tabular}{|c|c|c|c|c|c|}
\hline \multirow[b]{2}{*}{ Tissue } & \multicolumn{4}{|c|}{ Medium AVP } & \multirow{2}{*}{$\frac{\text { Tisue AVP }}{30^{*}}$} \\
\hline & $0^{*}$ & $5^{*}$ & $15^{*}$ & $30 *$ & \\
\hline & \multicolumn{4}{|c|}{$p g i m l$} & $p g / g$ \\
\hline None & 43.0 & 53.5 & 39.5 & 37.0 & - \\
\hline Erythrocytes & 40.0 & 39.5 & 36.5 & 35.0 & - \\
\hline Kidney & 39.0 & 35.5 & 8.5 & $<1.0$ & $<1.25$ \\
\hline Liver & 37.4 & 30.0 & $<1.0$ & $<1.0$ & $<1.25$ \\
\hline
\end{tabular}

Flasks containing $2 \mathrm{~g}$ sliced rat liver or kidney, or 2-ml washed human erythrocytes were incubated at $37^{\circ} \mathrm{C}$ in $25 \mathrm{ml}$ of 0.04 $M$ phosphate buffer $(\mathrm{pH}=7.4)$ containing $0.14 \mathrm{M} \mathrm{NaCl}$, $1 \mathrm{mg} / \mathrm{ml}$ glucose, $2.5 \mathrm{mg} / \mathrm{ml}$ crystalline bovine serum albumin, and $40 \mathrm{pg} / \mathrm{ml}$ standard AVP. Immediately upon addition of the tissies, and at 5, 15, and $30 \mathrm{~min}$ thereafter, $1-\mathrm{ml}$ aliquots of the incubation media were subjected to the standard acetone extraction then assayed in volumes of $0.1 \mathrm{ml}$. The kidney and liver slices were homogenized in $2 \mathrm{ml}$ of $20 \%$ trichloroacetic acid, the supernate extracted with diethyl ether, neutralized with $0.1 \mathrm{~N}$ sodium hydroxide, and assayed in volumes of $0.2 \mathrm{ml}$.

* Duration of incubation in minutes. yielded a clear, protein-free extract of sufficient volume (approximately $0.7 \mathrm{ml}$ ) to permit assay of triplicate $0.2-\mathrm{ml}$ aliquots.

Assay procedures. Standard curves were prepared in duplicate by mixing $0.05 \mathrm{ml}$ of diluent containing $1,000 \mathrm{cpm}$ of $\left[{ }^{125} \mathrm{I}\right] \mathrm{AVP}$ ( $60 \%$ counting efficiency), $0.2 \mathrm{ml}$ of diluent containing $0.1-10 \mathrm{pg}$ of $\mathrm{AVP}_{\mathrm{B}}$ standard, $0.2 \mathrm{ml}$ of $0.14 \mathrm{M}$ saline, and $0.05 \mathrm{ml}$ of a $1: 125,000$-fold dilution of the G1-1 antiserum (prepared by diluting the $1: 10,000$ working stock 12.5 -fold with diluent). Unknowns were assayed in triplicate by replacing the $0.2 \mathrm{ml}$ of normal saline with an equal volume of acetone-extracted plasma. All samples were incubated in $10 \times 75-\mathrm{mm}$ disposable glass tubes (Kimax, Kimble Products) at $4^{\circ} \mathrm{C}$ for 7 days, then $0.05 \mathrm{ml}$ of $0.14 \mathrm{M}$ saline containing $16 \mathrm{mg} / \mathrm{ml}$ of rabbit $\gamma$-globulin was added, and the antibody-[ $\left.{ }^{125} \mathrm{I}\right] \mathrm{AVP}$ complex was immediately precipitated by the addition of $0.5 \mathrm{ml}$ of cold polyethylene glycol solution (5). The assay tubes were then centrifuged at $2,100 \mathrm{rpm}$ and $4^{\circ} \mathrm{C}$ for $1 \mathrm{~h}$, the supernate decanted into $12 \times 75-\mathrm{mm}$ disposable glass tubes, and the two fractions counted individually for $10 \mathrm{~min}$ or 6,000 counts in an automated deep-well gamma spectrometer with $60 \%$ counting efficiency. The ratio of antibody bound-to-free $\left[{ }^{125} \mathrm{I}\right] \mathrm{AVP}$ $(B / F)$ was calculated for each sample and expressed as a percent of the $\mathrm{B} / \mathrm{F}$ obtained in the absence of unlabeled hormone (usually 1.1-1.4). A value of $90 \%$ was defined as the limit of detectability for the assay. Nonspecific precipitation of $\left[{ }^{125} \mathrm{I}\right] \mathrm{AVP}$, determined by incubating without vasopressin antiserum, was consistently less than $5 \%$.

\section{RESULTS}

Assay sensitivity and specificity. When used as described, the Gl-1 antiserum can consistently detect a minimum of $0.1 \mathrm{pg}(0.04 \mu \mathrm{U})$ of the purified AVP standard, with the most sensitive and precise portion of the standard curve extending to about 2 pg (Fig. 1A). The other preparation of purified natural vasopressin, $A V P_{G}$, yielded a displacement curve almost identical with that obtained with $\mathrm{AVP}_{\mathrm{B}}$ (not shown). On a weight basis, the AVPs was about $15 \%$ less reactive than $\mathrm{AVP}_{\mathbf{B}}$ (Fig. 1A), but when compared on the basis of their respective biologic potencies, $A V P s$ appeared to be slightly more immunoreactive than $\mathrm{AVP}_{\mathbf{B}}$ (Fig. 1B). Synthetic LVP, AVT, and OXY were, respectively, about $1 / 3,1 / 6$, and $1 / 100$ as reactive as $\mathrm{AVP}_{\mathbf{B}}$ (Fig. 1B). Standard AVP was rapidly and completely converted to an immunologically unreactive form by incubation with rat kidney or liver slices but was not effected by incubation with human erythrocytes (Table I). The addition of $0.2-\mathrm{ml}$ aliquots of saline containing heparin in concentrations two fold greater than the plasma and acetone in amounts sufficient to cause a strongly positive nitroprusside reaction had no affect on the $\mathrm{AVP}_{\mathbf{B}}$ standard curve (not shown).

The addition to the assay of $0.2-\mathrm{ml}$ volumes of plasma from normal subjects in various states of water balance produced depressions in the $\mathrm{B} / \mathrm{F}$ that were equivalent to 3-11 pg of $\mathrm{AVP} / \mathrm{ml}$ of plasma (Table II). However, this immunoreactivity did not cross-react like standard 
AVP (Fig. 2A) and, when subjected to gel chromatography, demonstrated distinct heterogeneity (Fig. 3A). Thus, when $1 \mathrm{ml}$ of plasma containing an abnormally high level of endogenous immunoreactivity was filtered on G-25 Sephadex, two immunoreactive components were recovered. The major component, containing a total of about $23 \mathrm{pg}$ of AVP, eluted after the salt in a position identical with that of standard AVPB. A second component, immunologically equivalent to about $3-4$ pg of AVP, eluted in the void volume with the plasma proteins. Similar patterns of immunoreactivity were observed in two other plasmas containing normal levels of endogenous AVP (not shown).

Subjecting plasma to acetone extraction eliminated most of the plasma proteins (adsorption at $280 \mathrm{~nm}$ ), as well as virtually all of the immunoreactivity associated with this fraction. Thus, when an acetone extract from 1 $\mathrm{ml}$ of the same plasma was filtered on Sephadex, only one immunoreactive component, that eluting like AVP, was found (Fig. 3B). The total immunoreactivity recovered in this fraction ( $16.7 \mathrm{pg}$ or $73 \%$ of the $22.7 \mathrm{pg}$ found in whole plasma) was commensurate with the volume of plasma water recovered during the extraction procedure $(0.7 \mathrm{ml}$ from $1 \mathrm{ml}$ of whole plasma). When assayed directly, over a 10 -fold range of dilutions, these acetone-extracted plasmas were also immunologically indistinguishable from $\mathrm{AVP}_{\mathbf{B}}$ (Fig. 2B).

The amount of non-AVP (acetone precipitable) immunoreactivity in plasma did not correlate with the state of hydration or the amount of true AVP present. When $0.2-\mathrm{ml}$ aliquots of whole and acetone-extracted plasmas were assayed in parallel, the values obtained in the extracts were consistently lower than the values for whole plasma. Under standard assay conditions this difference appeared to be immunologically equivalent to about $2-4 \mathrm{pg} / \mathrm{ml}$ of AVP (Table II). Whole plasma, added to an assay, also was found to cause a significant fall in the immunologic reactivity of the $\left[{ }^{125} \mathrm{I}\right] \mathrm{AVP}$ during incubation. Thus, when $0.2-\mathrm{ml}$ aliquots of whole plasma were incubated with $\left[{ }^{205} \mathrm{I}\right] \mathrm{AVP}$ under standard assay conditions, there was a progressive fall, of about $15-30 \%$, in the proportion of the $\left[{ }^{125} \mathrm{I}\right] \mathrm{AVP}$ bindable by the subsequent addition of excess vasopressin antiserum (Fig. 4A). Extraction with acetone totally eliminated the capacity of whole plasma to alter the immunoreactivity of the $\left[{ }^{125} \mathrm{I}\right] \mathrm{AVP}$ (Fig. $4 \mathrm{~B}$ ).

Acetone extracts of plasma from normal subjects undergoing maximal water diuresis often contain small but readily detectable amounts of immunoreactivity (vide infra). To characterize this, a large volume of plasma from a water-loaded normal subject, was extracted, desalted, and concentrated by an ion-exchange technique, (6) and the residue was subjected to chromatographic and immunologic tests of identity (Fig. 5).

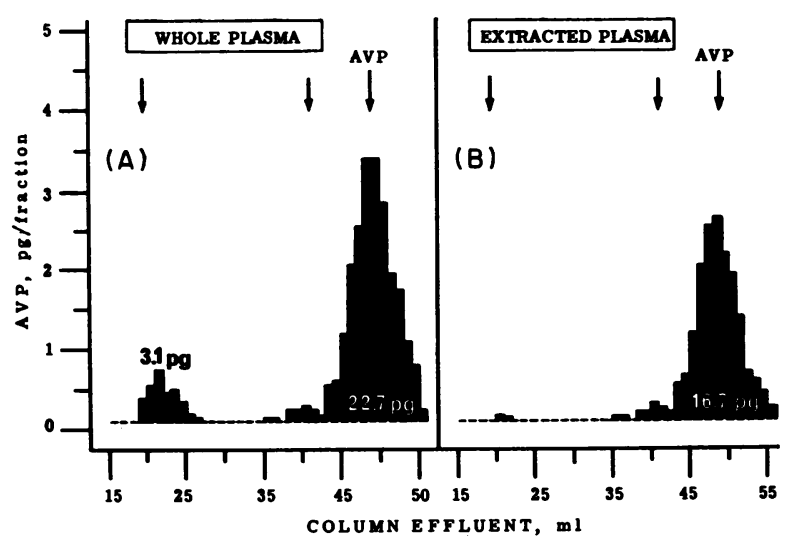

FigURE 3 Gel chromatography of plasma immunoreactivity before and after acetone extraction. (A) $1 \mathrm{ml}$ of whole plasma was chromatographed on a $2 \times 16 \mathrm{~cm}$ column of G-25 Sephadex in $0.0375 \mathrm{M} \mathrm{NH}_{4} \mathrm{COOCH}_{3}$ at $4^{\circ} \mathrm{C}$, the eluate collected in 1-ml aliquots, lyophilized, redissolved in $0.2 \mathrm{ml}$ of normal saline, and assayed by the standard method. (B) The acetone extract (total volume $0.7 \mathrm{ml}$ ) from $1 \mathrm{ml}$ of the same plasma was chromatographed and assayed in the same way. The immunoreactivity recovered in each 1 $\mathrm{ml}$ fraction was expressed as the amount of $A V P_{B}$ standard that produced an equivalent depression of tracer binding in the assay. The total immunoreactivity recovered in each of the major chromatographic components is indicated by the associated figures. The broken lines across the bottom of each panel indicates the sensitivity limits of the assay. The three vertical arrows across the top represent, from left to right, the elution volume of the plasma proteins (A at 280 $\mathrm{nm}$ ), the plasma salt (conductance), and standard $\mathrm{AVP}_{\mathbf{B}}$ (immunoassay).

Almost all (90\%) of the immunoreactivity present in the initial acetone extract of the plasma was recovered by this procedure and proved to be chromatographically

TABLE II

Immunoreactivity in Whole and Acetone-Extracted Plasma

\begin{tabular}{cccc}
\hline & \multicolumn{3}{c}{ Immunoassay values* } \\
\cline { 2 - 4 } Condition & 4.2 & 1.1 & 3.1 \\
& $\begin{array}{c}\text { Whole } \\
\text { plasma }\end{array}$ & $\begin{array}{c}\text { Extracted } \\
\text { plasma }\end{array}$ & Difference \\
\hline Water loaded & 3.1 & 0.5 & 2.6 \\
Ad lib. fluids & 7.8 & 3.8 & 4.0 \\
& 5.2 & 2.2 & 3.0 \\
Fluid restriction & 10.8 & 7.8 & 3.0 \\
& 9.8 & 6.3 & 3.5 \\
& & & Mean $\pm \mathrm{SD}$ \\
& & & $3.2 \pm 0.5$ \\
\hline
\end{tabular}

Radioimmunoassay was performed on $0.2-\mathrm{ml}$ aliquots of normal plasma before and after acetone extraction. The difference between each pair of values is shown in the right-hand column.

${ }^{*}$ Expressed as picograms of $\mathrm{AVP}_{\mathrm{B}}$ per milliliter original plasma or extract. 


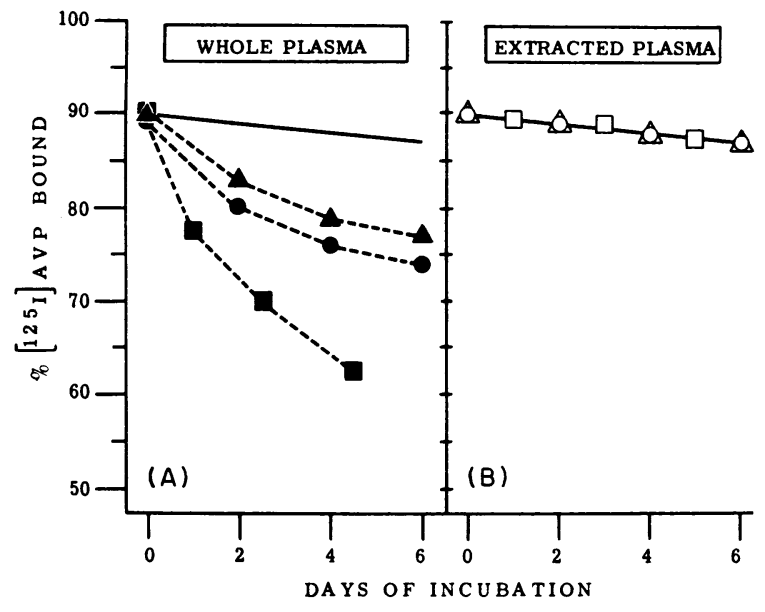

Figure 4 The effect of whole and acetone-extracted plasma on the immunologic reactivity of $\left[{ }^{125} \mathrm{I}\right] \mathrm{AVP}$. Assay tubes containing $0.2-\mathrm{ml}$ aliquots of either whole (A) or acetoneextracted (B) plasma as well as the usual amounts of diluent, G1-1 antiserum and $\left[^{125} \mathrm{I}\right] \mathrm{AVP}$ were prepared. After incubation for $0-6$ days, at $4^{\circ} \mathrm{C}$, excess vasopressin antiserum was added and the incubation continued for an additional $18 \mathrm{~h}$ before precipitating antibody-bound $\left[{ }^{125} \mathrm{I}\right] \mathrm{AVP}$ with polyethylene glycol. The percent of $\left[{ }^{12 \pi} \mathrm{I}\right] A V P$ precipitable at each interval is shown on the vertical axis. Panel A shows the effect of whole plasma from three normal, nonpregnant subjects (closed figures) and panel $\mathrm{B}$ the effects of the same three plasmas after acetone extraction (open figures). The effect of incubation with diluent alone is shown by the solid line in both panels.

and immunologically indistinguishable from standard AVP pituitary diabetes insipidus whose plasma also contained small amounts of residual immunoreactivity (not shown).

Recovery of $A V P$ from plasma. When physiologic amounts of standard AVP were added to an AVP-deficient plasma and carried through the standard extraction and assay procedure, the recovery was virtually complete regardless of the amount of AVP added ( Table III). Allowing the plasma to stand at room temperature for up to $1 \mathrm{~h}$ or repeated freezing and thawing did not alter the recovery of AVP (Table III). However, storage of plasmas at $-20^{\circ} \mathrm{C}$ for more than $24 \mathrm{~h}$ regularly resulted in a significant decline in immunoassayable AVP (Fig. 6A). The rate of loss was greatest during the first $3 \mathrm{wk}$ of storage, by which time plasma AVP levels had declined to $58 \pm 9 \%$ (SD) of the amounts initially present in fresh plasma. After this, the rate of loss of activity was much less, averaging less than 5\% a month over a 6 mo period (Fig. 6B). Attempts to prevent the initial loss of activity by the use of plastic storage vials or the addition of dry-ice chips or Trasylol (FBA Pharmaceuticals Inc., New York) have not been uniformly successful. When samples of serum and plasma were collected simultaneously and assayed in parallel both before and after storage, the levels of AVP in serum were almost always lower, by from 10 to $90 \%$, than the levels in plasma (Table IV).

Precision and reproducibility of the assay. The intraassay coefficient of variation, determined by performing quadruplicate assays on the acetone extract from each of 40 different plasma samples, was related to the concentration of AVP in the sample; in 9 samples with increased plasma AVP ( $>5 \mathrm{pg} / \mathrm{ml}$ ), it averaged $7 \%$; in 20 samples with normal levels of plasma AVP, (1-5 pg/ $\mathrm{ml}$ ) it averaged $13 \%$; in 11 samples with low levels of plasma AVP $(<1 \mathrm{pg} / \mathrm{ml})$, it averaged $25 \%$. The interassay coefficient of variation was determined by performing 16 separate assays over a 6 mo period on a large pool of normal plasma. The mean $( \pm S D)$ plasma AVP on this pool was $2.5 \pm 0.4 \mathrm{pg} / \mathrm{ml}$ for an overall interassay coefficient of variation of $17 \%$.

Clinical results. In 12 normal, recumbent subjects on ad lib. intake of food and water, the mean $( \pm S D)$ plasma osmolality and AVP concentration were $287 \pm 2.1$ $\mathrm{mosmol} / \mathrm{kg}$ and $2.7 \pm 1.4 \mathrm{pg} / \mathrm{ml}$, respectively. After $16-20$ $\mathrm{h}$ of complete fluid restriction, these values increased significantly to $292 \pm 5.2 \mathrm{mosmol} / \mathrm{kg}$ and $5.4 \pm 3.4 \mathrm{pg} / \mathrm{ml}$ $(P<0.005$ by paired $t$ test $)$. In 15 normal subjects, the

TABLE III

Recoiery of A VP from IThole Plasma

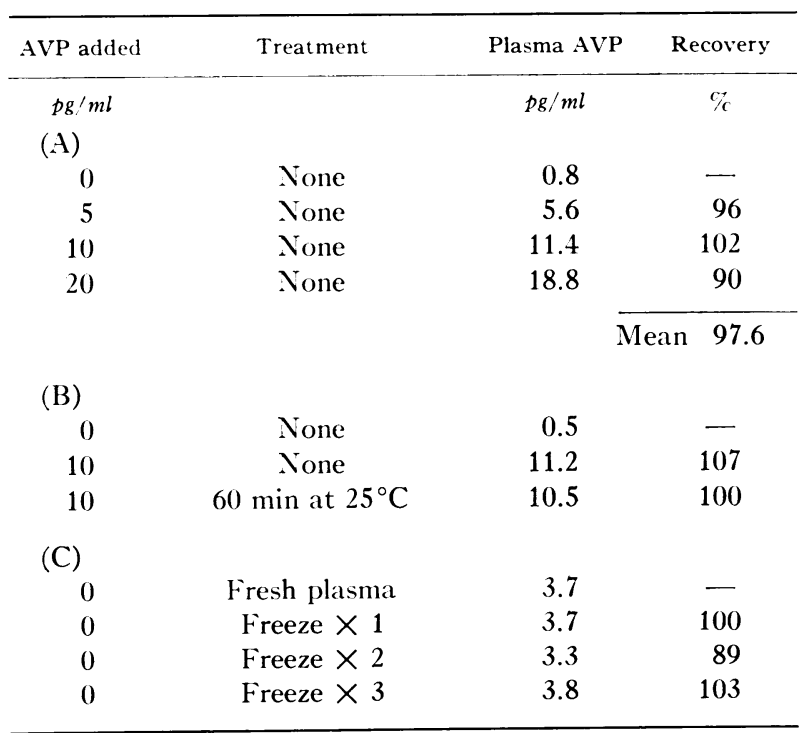

Variable amounts of $\mathrm{AVP}_{\mathrm{B}}$ were added to $1-\mathrm{ml}$ aliquots of whole plasma from a water-loaded normal subject, then exracted, and assayed immediately (A) or after incubation for $1 \mathrm{~h}$ at $25^{\circ} \mathrm{C}$ (B). Fresh plasma, obtained from a normal subject on ad lib. fluid intake, was extracted and assayed immediately and then again after rapid freezing and thawing in acetone and dry ice (C). 
administration of an oral water load $\left(20 \mathrm{~cm}^{3} / \mathrm{kg}\right)$ resulted in a significant fall $(P<0.005$ by paired $t$ test $)$ in plasma osmolality and AVP from initial mean $( \pm \mathrm{SD})$ values of $290 \pm 4.4 \mathrm{mosmol} / \mathrm{kg}$ and $3.0 \pm 1.5 \mathrm{pg} / \mathrm{ml}$, respectively, to $282 \pm 4.8 \mathrm{mosmol} / \mathrm{kg}$ and $1.4 \pm 0.8 \mathrm{pg} / \mathrm{ml}$, $60 \mathrm{~min}$ after water ingestion.

In normal recumbent subjects, a significant correlation between plasma AVP and plasma osmolality was observed (Fig. 7). At plasma osmolalities below 280 mosmol $/ \mathrm{kg}$, plasma AVP was low, but usually detectable, in the range of $0.5-1.5 \mathrm{pg} / \mathrm{ml}$. Above 280 mos$\mathrm{mol} / \mathrm{kg}$, plasma AVP ( $\mathrm{P}_{\Delta \mathrm{PP}}$ ) increased in proportion with plasma osmolality (Poss) according to the formula $P_{\triangle V P}=0.38$ (Poss -280 ), in which 0.38 represents the slope of the regression line and 280 its intercept on the $X$ or osmolality axis. The correlation coefficient for this relationship $(r=0.52)$ was highly significant $(P<0.001)$.

In eight untreated patients with pituitary (vasopres$\sin$ responsive) diabetes insipidus, the mean $( \pm \mathrm{SD})$ plasma osmolality and plasma AVP on ad lib. intake of food and water, were $295 \pm 5.8 \mathrm{mosmol} / \mathrm{kg}$ and $0.8 \pm 0.3$ $\mathrm{pg} / \mathrm{ml}$, respectively. After variable periods of fluid restriction, plasma AVP usually increased but to a degree
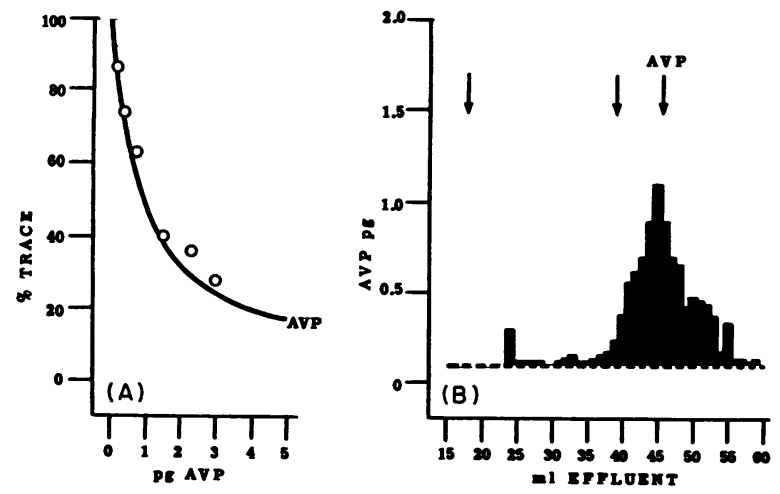

FIGCRE 5 The immunologic and chromatographic characteristics of the immunoreactivity found in plasma during water diuresis. $16 \mathrm{ml}$ of plasma was collected from a recumbent normal subject during maximal water diuresis (urine osmolality $60 \mathrm{mosmol} / \mathrm{kg}$ ). $1 \mathrm{ml}$ of this plasma was extracted and assayed by standard methods and found to contain the equivalent of $1.5 \mathrm{pg} / \mathrm{ml}$ of AVP. The remaining $15 \mathrm{ml}$ of plasma was deproteinized with $10 \%$ trichloroacetic acid, then adsorbed on an ion-exchange column (Rexyn 102H, Fisher Scientific Co., Pittsburgh, Pa.), eluted with $50 \%$ acetic acid, then lyophilized, and redissolved in exactly $1.5 \mathrm{ml}$ of normal saline. Portions of this, in volumes ranging from 0.01 to $0.2 \mathrm{ml}$, were subjected to direct radioimmunoassay $(A)$. The remainder $(0.95 \mathrm{ml})$ was subjected to gel chromatography and assay (B) as described in Fig. 3. The eluate from the ion-exchange column contained the immunologic equivalent of $20 \mathrm{pg}$ of AVP, representing an overall recovery of $90 \%$. Of that portion subjected to gel chromatography (12.6 pg), approximately $11 \mathrm{pg}(87 \%)$ eluted in a position identical with standard AVP.

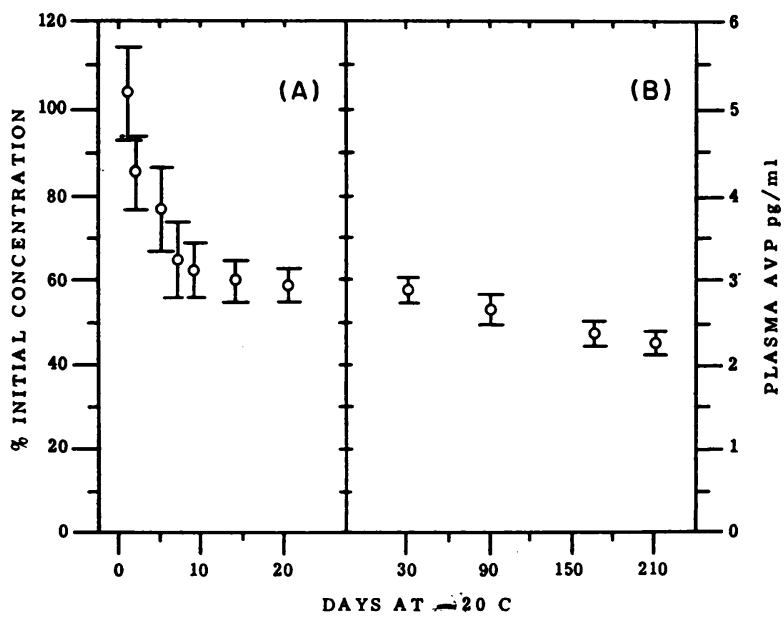

Figure 6 The stability of endogenous plasma AVP on storage. (A) Heparinized plasma samples were obtained from five normal subjects (three male and two female) on ad lib. fluid intake. A portion of each sample was extracted and assayed immediately and the remaining plasma stored in glass at $-20^{\circ} \mathrm{C}$. At intervals of $1-21$ days later, additional aliquots of each plasma were extracted and assayed, and the results expressed as a percent of the AVP concentration initially found in the fresh plasma. Each point represents the mean ( $\pm S D$ ) percent recovery for the five samples after storage for the times indicated on the horizontal axis. Plasma AVP concentration in the original samples averaged 3.8 (range 2.3-5.5) $\mathrm{pg} / \mathrm{ml}$. (B) A large number of normal, heparinized plasma samples that had been stored at $-20^{\circ} \mathrm{C}$ for $4-5$ wk were pooled, redivided into individual $1-\mathrm{ml}$ aliquots, and stored in glass at $-20^{\circ} \mathrm{C}$. Duplicate aliquots were extracted and assayed at 1-2-wk intervals over the next 6 mo. Each point represents the mean $( \pm \mathrm{SD}$ ) plasma AVP value of at least five separate assays performed during consecutive 1-2-mo intervals.

that was markedly subnormal relative to the plasma hypertonicity present (Fig. 7). However, in the nine samples obtained from four patients in whom the polyuria was due either to primary polydipsia or nephrogenic (vasopressin resistant) diabetes insipidus, the relationship of plasma AVP to plasma osmolality did not differ appreciably from that found in normal subjects (Fig. 7).

The relationship of plasma AVP to urinary concentration was also investigated by obtaining simultaneous collections of plasma and urine from 23 healthy subjects in various states of hydration (Fig. 8). Despite considerable variation in urinary solute excretion (range 0.18-1.3 $\mathrm{mosmol} / \mathrm{min}$ ), a significant correlation between urine osmolality and plasma AVP was found. At plasma AVP concentrations above $5 \mathrm{pg} / \mathrm{ml}$, concentration of the urine was usually maximal $(>1,100 \mathrm{mosmol} / \mathrm{kg})$. Below $5 \mathrm{pg} / \mathrm{ml}$, urinary osmolality (Uoss) decreased in proportion with plasma AVP ( $\mathrm{P}_{\mathrm{ArP}}$ ), as described by formula $U_{o S M}=250\left(P_{A V P}-0.25\right)$, in which 250 represents the slope of the regression line and 0.25 its inter- 
cept on the $X$ or plasma AVP axis. The correlation coefficient for this relationship $(r=0.77)$ was highly significant $(P<0.001)$.

In 24 sample pairs obtained from 8 patients with pituitary diabetes insipidus, the relationship between urine osmolality and plasma AVP concentration did not seem to differ markedly from that found in normal subjects (Fig. 8). In two patients with primary polydipsia, this relationship also was relatively normal, although urinary osmolality did not exceed $900 \mathrm{mosmol} / \mathrm{kg}$ in either patient despite plasma AVP concentrations in excess of $5 \mathrm{pg} / \mathrm{ml}$ and relatively low rates of solute excretion $(<0.4 \mathrm{mosmol} / \mathrm{min})$. In both patients with congenital nephrogenic diabetes insipidus, urine osmolality was consistently less than $150 \mathrm{mosmol} / \mathrm{kg}$ despite plasma AVP concentrations as high as $15 \mathrm{pg} / \mathrm{ml}$.

A short infusion of the ganglionic-blocking drug trimethaphan (Arfonad, Roche Labs. Div., Hoffmann-La Roche, Inc., Nuttley, N. J.) in a water-loaded normal subject resulted in a rapid fall in mean arterial blood pressure of about $25 \%$ and a marked rise in plasma AVP from 1.5 to $30 \mathrm{pg} / \mathrm{ml}$ (Fig. 9). When the trimethaphan infusion was stopped, blood pressure gradually returned to normal and plasma AVP fell, reaching basal levels in about $30 \mathrm{~min}$. In two other subjects in

TABLE IV

Comparison of the AVP Content of Plasma and Serum

\begin{tabular}{|c|c|c|c|}
\hline & \multicolumn{2}{|c|}{ AVP concentration } & \multirow{2}{*}{$\begin{array}{l}\text { Difference, } \\
\text { Serum 'plasma } \\
\times 100\end{array}$} \\
\hline & Pla:ma & Serum & \\
\hline & \multicolumn{2}{|c|}{$p g ' m l$} & \\
\hline \multirow[t]{6}{*}{ (A) 30 min at $4^{\circ} \mathrm{C}$} & 6.5 & 6.7 & 103 \\
\hline & 5.0 & 2.6 & 52 \\
\hline & 4.7 & 0.7 & 15 \\
\hline & 3.0 & 0.9 & 30 \\
\hline & 1.5 & 0.5 & 33 \\
\hline & & & $\begin{array}{c}\text { Mean } \pm \text { SEM } \\
47 \pm 15 \%\end{array}$ \\
\hline \multirow[t]{6}{*}{ (B) $6 \mathrm{wk}$ at $-20^{\circ} \mathrm{C}$} & 6.2 & 0.5 & 8 \\
\hline & 2.1 & 1.1 & 52 \\
\hline & 1.8 & 1.7 & 94 \\
\hline & 1.7 & 0.5 & 29 \\
\hline & 1.4 & 0.7 & 50 \\
\hline & & & $\begin{array}{c}\text { Mean } \pm \text { SEM } \\
47 \pm 14 \%\end{array}$ \\
\hline
\end{tabular}

$20 \mathrm{ml}$ of venous blood was drawn with a plastic syringe from 10 nonpregnant normal subjects, quickly divided between two chilled $10-\mathrm{ml}$ vacutainers containing either lithium heparin or no anticoagulant, then centrifuged for $20 \mathrm{~min}$ at $4^{\circ} \mathrm{C}$. The serum and plasma pairs from five of the subjects were extracted and assayed immediately (A), and those from the other five subjects after storage for $6 \mathrm{wk}$ at $-20^{\circ} \mathrm{C}(\mathrm{B})$.

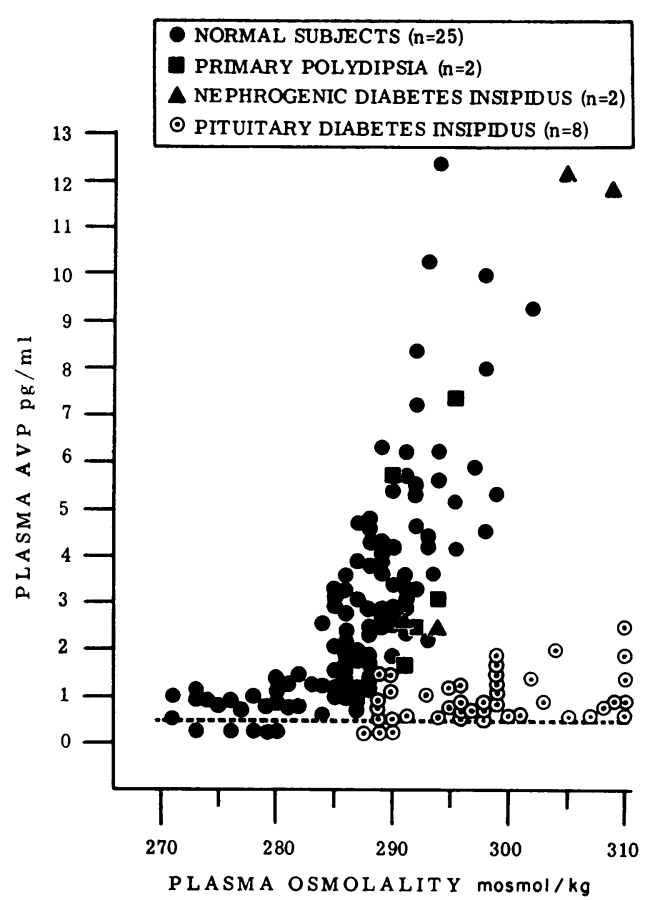

FigUre 7 The relationship of plasma AVP to plasma osmolality in normal subjects and patients with polyuria of diverse etiologies. Plasma was collected from recumbent subjects in three states of water balance $(a)$ ad lib. fluid intake, (b) $90 \mathrm{~min}$ after an acute water load $\left(20 \mathrm{~cm}^{3} / \mathrm{kg}\right)$, and $(c)$ after variable periods of fluid restriction. Osmolality and AVP were determined as described. Regression analysis of all samples from normal subjects in which osmolality was greater than $280 \mathrm{mosmol} / \mathrm{kg} \quad(n=87)$, showed a highly significant correlation $(r=0.52 P=$ $<0.001$ ) between plasma AVP concentration and plasma osmolality. The horizontal broken line represents the sensitivity limit of the plasma AVP assay.

whom mean arterial blood pressure was reduced by about 12 and $5 \%$, the resultant rise in plasma AVP was proportionately smaller at 4.8 and $1.8 \mathrm{pg} / \mathrm{ml}$, respectively (not shown).

The administration of small amounts of posterior pituitary extract (Pitressin, Parke, Davis \& Co., Detroit, Mich.) to patients with pituitary diabetes insipidus consistently resulted in readily detectable increases in plasma vasopressin as well as urinary osmolality. When solute excretion rate was maintained relatively constant, the correlation between these two variables was quite close (Fig. 10). Thus, before the administration of Pitressin to patient O. C., plasma AVP was barely detectable, at about $0.6 \mathrm{pg} / \mathrm{ml}$, and urine osmolality was correspondingly low, at about $100 \mathrm{mosmol} / \mathrm{kg}$. A constant infusion of Pitressin, at a rate calculated from the supplier's assigned potency at $50 \mu \mathrm{U} / \mathrm{min}$ and from immunoassay values as $100 \mathrm{pg} / \mathrm{min}$, resulted in a progressive increase in plasma vasopressin and urinary osmo- 
lality to values of about $1.1 \mathrm{pg} / \mathrm{ml}$ and $170 \mathrm{mosmol} / \mathrm{kg}$, respectively. Doubling the rate of Pitressin infusion resulted in a further rise in both plasma vasopressin and urine osmolality to about $1.7 \mathrm{pg} / \mathrm{ml}$ and $300 \mathrm{mosmol} / \mathrm{kg}$. Stopping the infusion resulted in a prompt fall of both variables toward baseline values. The decline in plasma vasopressin was semilogarithmic and had a half time of about $20 \mathrm{~min}$. Similar patterns of vasopressin clearance were observed after cessation of Pitressin infusion in four other patients with pituitary diabetes insipidus as well as in three normal subjects (Fig. 11). The mean $( \pm S D) t$ for plasma vasopressin in each of the two groups was $22.5 \pm 4$ and $19 \pm 5.6 \mathrm{~min}$, respectively.

\section{DISCUSSION}

The development of a clinically useful radioimmunoassay for plasma vasopressin has proven to be more difficult than for many of the other polypeptide hormones. Although a number of other laboratories have succeeded by a variety of methods in raising antisera to vasopressin (7-15), none has been sufficiently sensitive to detect the hormone at the low concentrations $\left(10^{-13} \mathrm{M}\right)$ normally present in plasma. Moreover, when carefully studied, several of these antisera have been found to be unusually susceptible to interference by a

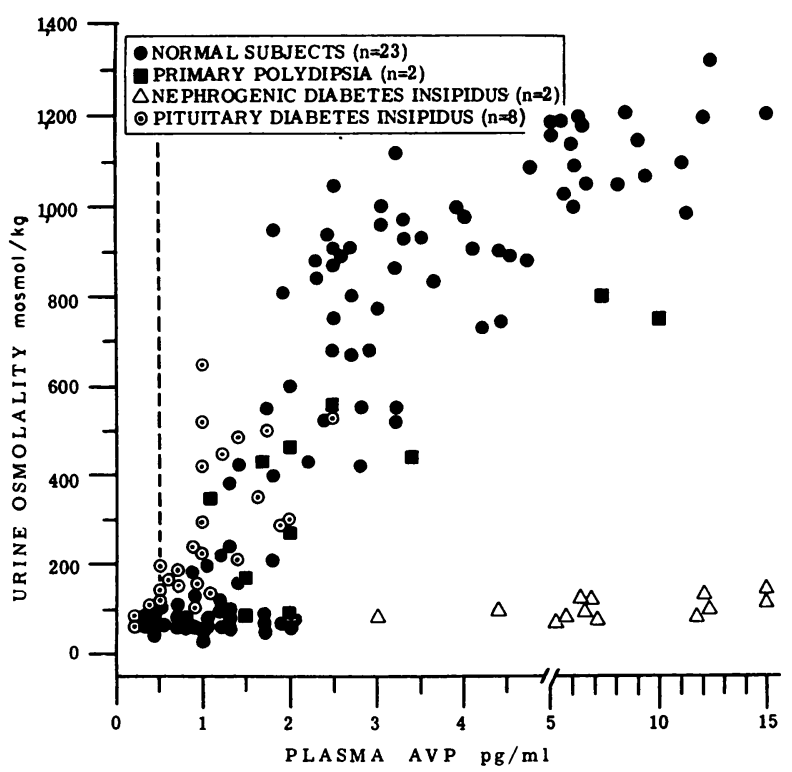

FigUre 8 The relationship of plasma AVP to urine osmolality in normal subjects and patients with polyuria of diverse etiology. Plasma and urine were collected simultaneously from recumbent subjects as described in Fig. 7. Regression analysis of all samples from normal subjects in which plasma AVP was $5 \mathrm{pg} / \mathrm{ml}$ or less $(n=87)$ showed a highly significant correlation $(r=0.77 P=<0.001)$ between plasma AVP and urine osmolality. The vertical broken line represents the sensitivity limit of the plasma AVP assay.

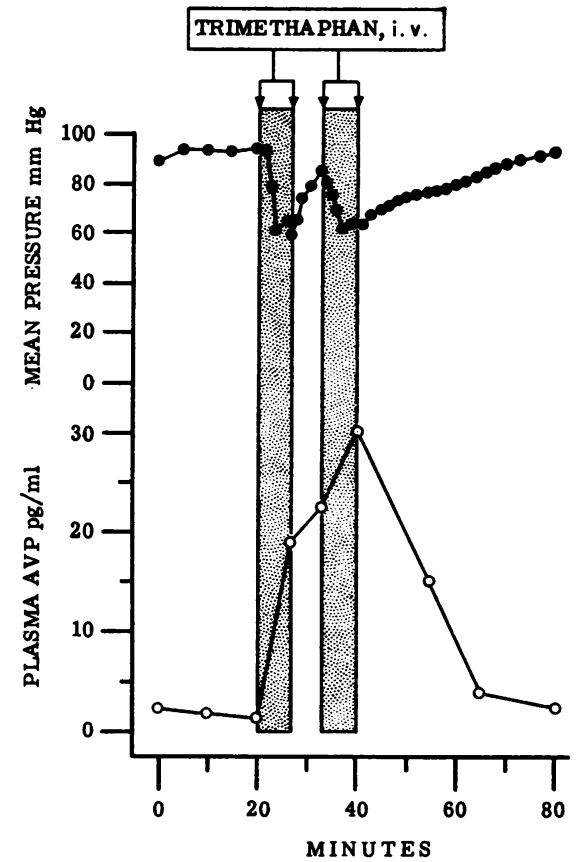

Figure 9 The effect of acute hypotension on plasma AVP in a healthy subject. Plasma AVP was determined before, during, and after an i.v. infusion of trimethaphan (Arfonad, Roche Labs., Div.) into a water-loaded adult male. Blood pressure was monitored at the brachial artery by sphygmomanometer and expressed as the mean of the systolic and diastolic values. Plasma osmolality remained at 280 mosmol/kg or less throughout the procedure.

variety of plasma components $(1,12)$. Because of these problems it previously has been necessary to extract chromatographically and concentrate plasma vasopressin before assay, a requirement that significantly limits the usefulness of the technique.

The acquisition of a new vasopressin antiserum (2) has now made possible a much simpler and more accurate method for the radioimmunoassay of plasma AVP. The special advantages of this antiserum are its greater sensitivity, which eliminates the need to concentrate plasma AVP before assay, and a lesser susceptibility to interference by nonhormonal components, which permits the use of much simpler extraction technique. The sensitivity of the assay, which is severalfold greater than previous methods, has been verified with three different AVP standards (Fig. 1). Allowing for the small amount of contamination known to be present in the AVPs, the agreement between these independently prepared standards was quite close. Because of this and other evidence for the purity of the $A V P_{B}$ standard, we have elected to express our results in terms of hormone weight. These can be readily converted to the more commonly used biologic units (microunits per milliliter) simply by multiplying by the 


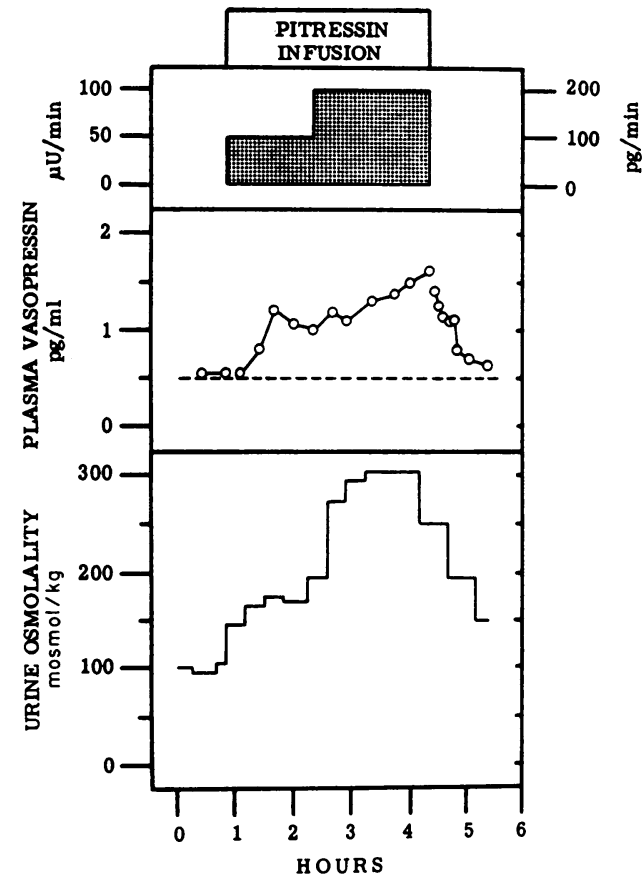

Figure 10 The relationship between Pitressin infusion rate, plasma vasopressin concentration, and urinary osmolality. A patient with vasopressin-responsive diabetes insipidus was given an i.v. infusion of $5 \%$ mannitol at a rate sufficient to maintain his solute excretion rate relatively constant at $1.43 \pm 0.11$ (SD) $\mathrm{mosmol} / \mathrm{min}$. After a $1 \mathrm{~h}$ control period, an i.v. infusion of Pitressin was administered at a rate which produced submaximal increases in urine osmolality. The actual infusion rates, shown in the upper panel are expressed both in terms of the supplier's assigned potency (microunits per minute) as well as the potency subsequently determined by immunoassay (picograms per minute). The broken line across the lower portion of the plasma vasopressin panel designates the sensitivity limit of the assay.

potency of our AVPB standard $(0.4 \mu \mathrm{U} / \mathrm{pg})$. Since the assay can ordinarily detect a minimum of $0.1 \mathrm{pg}$ of AVP and the largest volume of sample that can be accommodated is $0.2 \mathrm{ml}$, the lowest concentration of plasma AVP detectable is $0.5 \mathrm{pg} / \mathrm{ml}$. A further increase in sensitivity, of as much as three- to fourfold, can be obtained by incubating under nonequilibrium conditions, but this approach is not regularly used since the existing sensitivity seems to be adequate to measure physiologic levels of AVP.

The high degree of structural specificity shown by this antiserum greatly reduces the likelihood of crossreactions with peptides other than AVP. Even LVP and AVT, which differ from AVP by only one amino acid and have similar biologic properties, were less than $1 / 3$ and $1 / 6$ as reactive in the assay (Fig. $1 b$ ). This insensitivity to LVP and AVT is probably of no clinical importance (16) although a recent report claim- ing to identify AVT in the cerebrospinal fluid of man (17) suggests that this point needs to be investigated more fully (vide infra). The possibility that the assay might react with biologically inactive metabolites of AVP could not be tested directly since the identity of these substances is not yet known. However, we did find that the immunologic reactivity of AVP was rapidly and totally destroyed by incubation with liver or kidney (Table I), organs that are believed to be the principal sites of AVP degradation in vivo (18). Therefore, unless the inactivation of AVP normally proceeds by a different mechanism, it seems unlikely to result in products with an appreciable activity in our assay.

Despite the specificity shown by our assay, whole plasma consistently was found to contain an immunoreactive component that differed chromatographically as well as immunologically from the true AVP present. This nonhormonal activity, which was qualitatively and quantitatively different from that seen with our previous antiserum (1), constituted a small but significant proportion of the total immunoreactivity present and appeared to be confined to the macromolecular fraction of plasma. Although the nature of this atypical immunoreactivity has not been completely established, its "activity" in the assay probably is not due to competition for antibody-binding sites, but to a direct effect on the $\left[{ }^{125} \mathrm{I}\right] \mathrm{AVP}$ itself. This effect, which is often referred to as "damage," can be detected as a progressive decline in the immunologic reactivity of the $\left[{ }^{125} \mathrm{I}\right] \mathrm{AVP}$ during incubation with whole plasma (Fig. 4A). Since immunologically unreactive tracer would be expected to separate with the unbound $\left[{ }^{125} \mathrm{I}\right] \mathrm{AVP}$ in our assay procedure, this damage effect would result in a spurious lowering of the apparent $\mathrm{B} / \mathrm{F}$ value. The magnitude of the immunoactivity "blank" thus created can be estimated from the amount of $\left[{ }^{125} \mathrm{I}\right] \mathrm{AVP}$ damaged during incubation. Assuming no change in the fractional binding of the "undamaged" $\left[{ }^{125} \mathrm{I}\right] \mathrm{AVP}$, the conversion of $15-30 \%$ of the total $\left[{ }^{125} \mathrm{I}\right] \mathrm{AVP}$ to an immunologically unreactive form (Fig. 4A) should cause a fall in the apparent $\mathrm{B}, \mathrm{F}$ of $30-45 \%$, an effect equal to that of $0.5-0.8 \mathrm{pg}$ of AVP. When corrected to $1 \mathrm{ml}$ of plasma, this would give a value for the nonhormonal "blank" equivalent to about 2.5-4 pg of AVP, an amount similar both to the total activity recovered in the macromolecular fraction (Fig. 3A) and the difference determined by direct assay before and after acetone extraction (Table II). This result suggests that virtually all of the atypical or nonhormonal immunoactivity of plasma can be accounted for as damage to the tracer.

The cause of the damage effect has not been definitively established but is most likely due to an enzymatic alteration in the structure of the [ $\left.{ }^{125} \mathrm{I}\right] \mathrm{AVP}$ rather than to interference with tracer function by binding sub- 
stances in plasma. Recent observations in our laboratory, that the damage effect may be largely prevented by the addition of a protease inhibitor, Traysylol, is consistent with this view. Moreover, it is not yet clear whether or not significant vasopressin-binding activity really exists in plasma (18). Although neurophysin, the vasopressin-binding peptide of the posterior pituitary, is found there (19), its affinity for the hormone is too low to permit significant binding to occur at the concentrations that are normally found in plasma (20), much less at the fivefold greater dilutions that exist in our assay. Other factors such as the use of heparin, which has been reported to interfere with antigen-antibody reactions in some assays (21), is not apt to be responsible for the effects observed here since its addition directly to the assay had no effect on the $B / F$ and we find that serum seems to have an even greater tendency than plasma to cause tracer damage. Whatever the mechanism, however, the demonstration of this damage effect is important since it indicates that some kind of corrective measure will probably be necessary for all immunoassays of AVP in plasma or serum, regardless of the vasopressin antiserum used.

The acetone-extraction procedure used here effectively eliminates the interfering substances without altering, quantitatively or qualitatively, the AVP present. Thus, the activity recovered in the acetone extracts was immunologically (Fig. 2B) and chromatographically (Fig. 3B) indistinguishable from standard AVP and showed no tendency to "damage" $\left[{ }^{125} \mathrm{I}\right] \mathrm{AVP}$ (Fig. 4B). Although the extraction results in some loss of volume, the concentration of AVP in the extract is not significantly affected, and corrections for recovery are not necessary. This is shown both by the gel chromatography study, in which the recovery of AVP was identical with the recovery of plasma water (Fig. 3), as well as by the experiments in which known concentrations of standard AVP were added to plasma before extraction and assay (Table III). The accuracy of this approach depends primarily on the acetoneevacuation step. If significant amounts of acetone remain, the resultant plasma AVP values will be too low due to simple dilution whereas, if the evacuation proceeds too long, the values will be too high due to excess evaporation of water. When properly done, the volume of extract from $1 \mathrm{ml}$ of plasma should be between 0.6 and $0.7 \mathrm{ml}$ and contain no acetone by nitropusside testing. With practice, large numbers of samples can be extracted accurately and reproducibly, as shown both by the precise recoveries (Table III) and the relatively small interassay variability.

The major source of error in the measurement of plasma AVP appears to be the loss of activity that occurs during storage of the samples. Conditions that

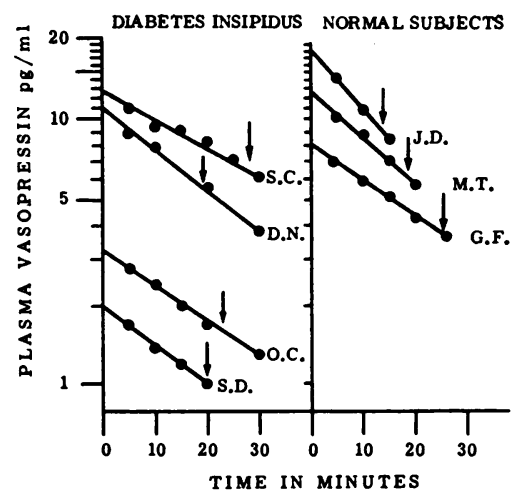

Figure 11 The decline of plasma vasopressin after constant i.v. infusion of Pitressin. Four patients with pituitary diabetes insipidus and three water-loaded normal subjects received constant i.v. infusions of Pitressin for periods of 60-120 min. Based on the supplier's assigned potency, the approximate rates of hormone infusion were: S. D., 50 $\mu \mathrm{U} / \mathrm{min}$; O. C., $250 \mu \mathrm{U} / \mathrm{min}$; D. N., $1,000 \mu \mathrm{U} / \mathrm{min}$; S. C., $1,500 \mu \mathrm{U} / \mathrm{min}$; G. F., $1,000 \mu \mathrm{U} / \mathrm{min} ; \mathrm{M} . \mathrm{T} ., 2,500 \mu \mathrm{U} / \mathrm{min}$; and J. D., 5,000 $\mu \mathrm{U} / \mathrm{min}$. Blood for plasma vasopressin determination was obtained from an indwelling catheter at $5-10$-min intervals after stopping the infusion.

might normally attend the processing of plasma, such as standing for up to $1 \mathrm{~h}$ at room temperature or repeat freezing and thawing, appear to have no effect on the level of immunoassayable AVP present (Table III). However, storage at $-20^{\circ} \mathrm{C}$ for periods of $24 \mathrm{~h}$ or more resulted in a progressive decline in AVP activity in all samples, regardless of the levels initially present (Fig. 6A). Unlike previous workers, who reported a similar decline in bioassayable plasma AVP during storage (22), we find that this loss of activity cannot be prevented by addition of dry-ice chips, nor by a variety of other maneuvers such as the use of plastic vials or the addition of Trasylol. Although the problem could be eliminated by assaying each sample immediately after collection, such an approach is not practical for clinical studies, where samples must often be collected at unscheduled or inconvenient times. Accordingly, we have elected to follow a procedure where samples are assayed uniformly after $4-8 \mathrm{wk}$ of storage, a time when all samples seem to have decayed to about the same degree and the rate of further loss of activity is minimal (Fig. 6B). Although this results in underestimating true plasma AVP levels by $45-50 \%$, variability due simply to temporal differences in decay is minimized, and the values obtained in different individuals, or in the same individual at different times, can be more meaningfully compared.

The validity of this approach to measuring plasma AVP is supported by the clinical results obtained. Plasma AVP concentrations were in the expected range (23), agreed well with those obtained by our previous 
more elaborate assay procedure (1), and appeared to fluctuate appropriately in response to variations in fluid intake. These changes in plasma AVP were found to correlate significantly with changes in plasma osmolality (Fig. 7), a relationship also observed with our previous technique (1) and more recently by others using bioassay (24) as well as immunoassay (12). As indicated by the equation describing this relationship, the osmoreceptor governing AVP release had a threshold around $280 \mathrm{mosmol} / \mathrm{kg}$ and, in agreement with the original conclusions of Verney (25), was sensitive to increases in plasma osmolality as small as $1 \%$. The sensitivity and reproducibility of this relationship makes it an extremely useful way for interpreting plasma AVP values. at least under normovolemic and normotensive conditions.

Exact comparisons between our values and those obtained by others is difficult because important physiologic variables, such as posture or plasma osmolality, often are not specified. In general, however, the results we obtain appear to be in reasonable agreement with those reported by others using both immunoassay (12) and bioassays (22, 26-28). Our average values obtained under "basal" condition (2.8 pg or $1.1 \mu \mathrm{U} / \mathrm{ml}$ of plasma) are about the same as those reported by Yoshida, Motohashi, Ibayahi, and Okinaka (26) (1.9 $\mu \mathrm{U} / \mathrm{ml}$ plasma) and Segar and Moore (27) $(0.4 \mu \mathrm{U} / \mathrm{ml}$ whole blood) but are slightly lower than those reported by Czaczkes, Kleeman, and Koenig (22) (2.6 $\mu \mathrm{U} / \mathrm{ml}$ plasma). After fluid restriction, the average values we obtain ( $5.4 \mathrm{pg}$ or $2.2 \mu \mathrm{U} / \mathrm{ml}$ ) are almost identical with the immunoassay value reported by Beardwell (12) ( $5.5 \mathrm{pg} / \mathrm{ml}$ corrected for recovery) but significantly lower than those reported by Ahmed. George, GonzalezAuvert, and Dingman (28) $(4.6 \mu \mathrm{L} / \mathrm{ml})$, Yoshida et al. (26) $(6.5 \mu \mathrm{U} / \mathrm{ml})$, and Czaczkes et al. (22) (8 $\mu \mathrm{U} / \mathrm{ml}$ after $12-16 \mathrm{~h}$ ) by bioassay. The reason for the discrepancy between the various assay methods is unclear but might be due to unspecified differences in the physiologic status of the subjects, to differences in potency of the various reference standards used, or to variable loss of activity during storage of the plasma samples. With one exception (22), other laboratories have not commented on the problem of losses during storage so it is impossible to tell what countermeasures, if any, may have been used. In view of the fact that both immunoassays tended to give lower values during dehydration than the bioassays, the possibility should also be considered that human plasma may contain one or more antidiuretic substances other than $\operatorname{AVP}(17$, 28). Comparative immunoassay-bioassay studies, in which the reference standards, storage, and extraction procedures are carefully controlled, will be needed to shed light on this interesting possibility.
Plasma AVP levels obtained by our method were found to correlate appropriately with the level of urinary concentration in normal subjects (Fig. 8). A highly significant relationship was observed at plasma AVP concentrations ranging from $0.5 \mathrm{pg} / \mathrm{ml}$, where urine was usually maximally dilute, to about $5 \mathrm{pg} / \mathrm{ml}$. where maximum urinary concentration was achieved. The ability of many water-loaded normal subjects to achieve maximal urinary dilution despite the persistence of small amounts of plasma immunoreactivity deserves special comment. Although the bioactivity of this material has not been determined, its immunologic and chromatographic similarity to AVP (Fig. 5) coupled with the insensitivity of our assay to biologically inactivated hormone (Table $I$ ), strongly suggests that this residual immunoreactivity is due to intact AVP. Thus, it is apparently not necessary to suppress plasma AVP to undetectable levels in order to develop a maximum diuresis in normal subjects. The possibility that these low levels of AVP represents a hormone that is biologically inactive due to plasma binding seems unlikely (vide supra) but cannot be excluded at this time.

It is well known that the secretion of vasopressin may be stimulated by a reduction in blood volume (29). We have found that isovolemic hypotension, produced by ganglionic blockage, also caused a significant rise in plasma AVP that quickly subsided when blood pressure was allowed to return to normal (Fig. 9). The observation that a reduction in mean arterial blood pressure of only $5 \%$ was associated with a small but detectable rise in plasma AVP suggests that even modest changes in blood pressure may have important effects on AVP secretion and should be carefully monitored in studies of hormone function.

The levels of plasma AVP determined by our assay also conformed well to pathophysiologic expectations in patients with various types of polyuria. In all eight patients with acquired pituitary diabetes insipidus, the levels of plasma immunoreactivity were distinctly subnormal relative to the degree of plasma hyperosmolality present (Fig. 7). These levels of immunoreactivity tended to increase slightly during severe dehydration and usually were associated with the appropriate levels of urine osmolality (Fig. 8) suggesting that many patients with acquired pituitary diabetes insipidus retain some capacity to secrete small but physiologically inadequate amounts of AVP. In contrast, plasma AVP appeared to be completely normal relative to plasma osmolality in patients with primary polydipsia and nephrogenic diabetes insipidus. These findings, which confirm and extend those previously reported (30), are a further indication that neither chronic over-hydration nor under-hydration appreciably alters the responsiveness of the osmotic control mechanism. Urine osmo- 
lality also demonstrated the expected abnormal relationship to plasma AVP in patients with primary polydipsia (31) as well as nephrogenic diabetes insipidus (Fig. 8).

Pitressin infusion studies demonstrated a clear relationship between the rate of hormone administration and the resultant levels of plasma vasopressin as determined by radioimmunoassay (Figs. 10 and 11). Even with doses of Pitressin that caused only moderate changes in urinary osmolality, small increases in plasma immunoreactivity could be detected that were proportional both to the rate of hormone infusion and the accompanying changes in urine osmolality (Fig. 10). Since the Pitressin used did not appear to contain appreciable amounts of nonhormonal immunoreactivity (its immunologic potency was actually about $20 \%$ lower than might have been expected on the basis of its designated biologic potency) (Fig. 10), the observed changes in plasma immunoreactivity were probably due solely to vasopressin. This conclusion is also supported by the similarity between Pitressin clearance rates determined by immunoassay (Fig. 11) and those previously observed in man using bioassay (22). These findings suggest that, unless the other ingredients of Pitressin significantly alter the in vivo metabolism of the hormone, changes in endogenous AVP secretion sufficient to effect significant increases in urine concentration should also be accompanied by readily detectable increases in plasma AVP. Although this conclusion needs to be verified with purer preparations of AVP, it is fully compatible with the clinical results obtained (Fig. 8).

\section{ACKNOWLEDGMENTS}

We would like to thank Mrs. Karen Benninghoff, Mr. Thomas Brennan, Miss Mary Pratt, and Miss Frances Maeda for their expert technical assistance in the performance of these studies, and Mrs. Brenda Dillane for her patience and skill in the preparation of this manuscript.

This work was supported from the following sources: Veterans Administration Designated Research Funds (Dr. Robertson), U. S. Public Health Service-GRSG FR-5369. Hypertension SCORE Grant HL-14159, and Veterans Administration Training Grants in Endocrinology and Metabolism, TR-88 and TR-212.

\section{REFERENCES}

1. Robertson, G. L., L. A. Klein, J. Roth, and P. Gorden. 1970. Immunoassay of plasma vasopressin in man. Proc. Natl. Acad. Sci. U. S. A. 66: 1298.

2. Oyama, S. N., A. Kagan, and S. M. Glick. 1971. Radioimmunoassay of vasopressin: application to unextracted human urine. J. Clin. Endocrinol. Metab. 33: 739.

3. Acher, R., A. Light, and V. du Vigneaud. 1958. Purification of oxytocin and vasopressin by way of a protein complex. J. Biol. Chem. 233: 116.
4. Robertson, G. L., J. Roth, C. Beardwell, L. A. Klein, M. J. Petersen, and P. Gorden. 1973. Radioimmunoassay of vasopressin in man. In Methods in Investigative and Diagnostic Endocrinology. S. A. Berson and R. Yalow, editors. North-Holland Publishing Co., Amsterdam. IIA : 656.

5. Desbuquois, B., and G. D. Aurbach. 1971. Use of polyethylene glycol to separate free and antibody-bound peptide hormones in radioimmunoassays. J. Clin. Endocrinol. Metab. 33: 732.

6. Rogge, J. D., W. W. Moore, W. E. Segar, and A. F. Fasola. 1967. The effect of $+G_{z}$ and $+G_{x}$ acceleration on peripheral venous ADH levels in humans. J. Appl. Physiol. 23: 870.

7. Roth, J., S. M. Glick, L. A. Klein, and M. J. Petersen. 1966. Specific antibody to vasopressin in man. J. Clin. Endocrinol. Metab. 26: 671.

8. Permutt, M. A., C. W. Parker, and R. D. Utiger. 1966. Immunochemical studies with lysine vasopressin. Endocrinology. 78: 809.

9. Wu, W. H., and J. H. Rockey. 1969. Antivasopressin antibody. Characterization of high-affinity antibody with limited association constant heterogeneity. Biochemistry. 8: 2719 .

10. Miller, M., and A. M. Moses. 1969. Radioimmunoassay of vasopressin with a comparison of immunological and biological activity in the rat posterior pituitary. Endocrinology. 84: 557.

11. Menard, J., and P. Milliez. 1970. Système radio-immunologique pour le dosage de l'hormone antidiurétique. C. R. Acad. Sci. t270: 1053 .

12. Beardwell, C. G. 1971. Radioimmunoassay of arginine vasopressin in human plasma. J. Clin. Endocrinol. Metab. 33: 254.

13. Edwards, C. R. W., T. Chard, M. J. Kitau, and M. L. Forsling. 1970. The development of a radioimmunoassay and a plasma extraction method for vasopressin. J. Endocrinol. 48 : xi.

14. Johnston, C. I. 1972. Radioimmunoassay for plasma antidiuretic hormone. J. Endocrinol. 52: 69.

15. Skowsky, W. R., and D. R. Fisher. 1972. Vasopressin (VP) kinetics in man and the rhesus monkey fetus using radioimmunoassay (RIA) measurements. J. Clin. Invest. 51 : 91a. (Abstr.)

16. Sawyer, W. H. 1967. Evolution of antidiuretic hormones and their functions. Am. J. Med. 42: 678.

17. Pavel, S. 1970. Tentative identification of arginine vasotocin in human cerebrospinal fluid. J. Clin. Endocrinol. Metab. 31: 369.

18. Lauson, H. D. 1967. Metabolism of antidiuretic hormones. Am. J. Med. $42: 713$.

19. Robinson, A. G., E. A. Zimmerman, and A. G. Frantz. 1971. Physiologic investigation of posterior pituitary binding proteins neurophysin I and neurophysin II. Metab. Clin. Exp. 20: 1148.

20. Breslow, E., and R. Walter. 1972. Binding properties of bovine neurophysins I and II : an equilibrium dialysis study. Mol. Pharmacol. $8: 75$.

21. Reiss, E., and J. M. Canterbury. 1968. A radioimmunoassay for parathyroid hormone in man. Proc. Soc. Exp. Biol. Med. 128: 501.

22. Czaczkes, J. W., C. R. Kleeman, and M. Koenig. 1964. Physiologic studies of antidiuretic hormone by its direct measurement in human plasma. J. Clin. Invest. 43: 1625. 23. Lauson, H. B. 1960. Vasopressin and oxytocin in the 
plasma of man and other mammals. In Hormones In Human Plasma. H. N. Antoniades, editor. Little, Brown and Company, Boston. 1st edition. 225.

24. Moore, W. W. 1971. Antidiuretic hormone levels in normal subjects. Fed. Proc. 30 : 1387.

25. Verney, E. B. 1947. The antidiuretic hormone and factors which determine its release. Proc. R. Soc. Lond. B. Biol. Sci. 135: 25.

26. Yoshida, S., K. Motohashi, H. Ibayahi, and S. Okinaka. 1963. Method for the assay of antidiuretic hormone in plasma with a note on the antidiuretic titer of human plasma. J. Lab. Clin. Med. $62: 279$.

27. Segar, W. E., and W. W. Moore. 1968. The regulation of antidiuretic hormone release in man. I. Effects of change in position and ambient temperature on blood ADH levels. J. Clin. Invest. 47: 2143.
28. Ahmed, A. B. J., B. C. George, C. Gonzalez-Auvert, and J. F. Dingman. 1967. Increased plasma arginine vasopressin in clinical adrenocortical insufficiency and its inhibition by glucosteroids. J. Clin. Invest. 46: 111.

29. Share, L. 1969. Extracellular fluid volume and vasopressin secretion. In Frontiers in Neuroendocrinology. W. F. Ganong and L. Martini, editors. The Oxford University Press, London. 1st edition. 183.

30. Gorden, P., G. L. Robertson, and J. E. Seegmiller. 1971. Hyperuricemia, a concomitant of congenital vasopressinresistant diabetes insipidus in the adult. $N$. Engl. J. Med. 284: 1057.

31. DeWardener, H. E., and A. Herxheimer. 1957. The effect of a high water intake on the kidney's ability to concentrate the urine in man. J. Phy'siol. (Lond.). 139: 42 . 